\title{
An Optimized Microsatellite Scheme for Assessing Populations of Xanthomonas phaseoli pv. manihotis
}

\author{
Leidy Rache, ${ }^{1,2}$ Laurence Blondin, ${ }^{3}$ Carolina Flores, ${ }^{4}$ Cesar Trujillo, $, 2,5$ Boris Szurek, ${ }^{4}$ Silvia Restrepo, ${ }^{2}$ Ralf Koebnik, ${ }^{4}$ \\ Adriana Bernal, $1,2, \dagger$ and Christian Vernière 6,7 \\ ${ }^{1}$ Laboratorio de Interacciones Moleculares de Microorganismos Agrícolas (LIMMA), Universidad de los Andes, Bogotá D.C., Colombia; \\ ${ }^{2}$ Laboratorio de Micología y Fitopatología (LAMFU), Universidad de los Andes, Bogotá D.C., Colombia; ${ }^{3}$ Cirad, UR Bioagresseurs, F-34398 \\ Montpellier, France; ${ }^{4}$ IRD, Cirad, Université de Montpellier, IPME, Montpellier, France; ${ }^{5}$ Affiliated until 2015; ${ }^{6}$ Cirad, UMR BGPI, F-34398 \\ Montpellier, France; and ${ }^{7}$ BGPI, Université de Montpellier, Cirad, INRA, Montpellier SupAgro, Montpellier, France \\ Accepted for publication 14 December 2018.
}

\begin{abstract}
Diverse molecular markers have been used to analyze the genetic diversity of plant pathogens. Compared with traditional fingerprinting methods, multiple loci variable number of tandem repeat analyses (MLVAs) have gained importance recently due to their reproducibility, high discriminatory power, ease of performance, low cost, and throughput potential. These characteristics are desirable for continuous pathogen monitoring, especially for pathogens with relatively low genetic diversity, and for disease epidemiology studies. Genetic diversity studies of Xanthomonas phaseoli pv. manihotis, which is the causal agent of cassava bacterial blight, have shown variability and changes in the bacterial population over time. Thus, an easy and fast method needs to be developed to type populations of this pathogen in different countries of the world, especially on small scales. In this study, we developed an MLVA scheme to analyze X. phaseoli pv. manihotis variability on a local scale. The MLVA-15 scheme comprises 15 variable

fragment length polymorphisms. The MLVA-15 scheme allowed for an accurate determination of the number of genotypes in the sample and showed reproducibility and portability. Additionally, this scheme could be used to analyze numerous strains in a reasonable timeframe. The MLVA-15 scheme was highly specific to X. phaseoli but up to eight tandem repeat loci could be amplified from other Xanthomonas spp. Finally, we assessed the utility of the scheme for analyses of $X$. phaseoli pv. manihotis genetic variability in the Colombian Caribbean region. MLVA-15 distinguished $88.9 \%$ of the haplotypes in our sample. Strains originating from the same field and isolated at the same time could be discriminated. In this study, the advantages of the MLVA-15 scheme targeting 6- or 7-bp repeats were demonstrated. Moreover, this scheme was a fast method that was appropriate for routine monitoring of $X$. phaseoli pv. manihotis populations on a local scale and, thus, was useful for addressing epidemiological questions.
\end{abstract} number of tandem repeat loci grouped into four multiplex polymerase chain reaction pools. We showed that the MLVA-15 scheme had slightly higher discriminatory ability at the locality level when compared with amplified
Keywords: epidemiology, molecular marker, pathogen diversity, tandem repeat, Xanthomonas.
Good assessment of genetic variability is necessary to decipher the population structures and epidemiology of plant pathogens. Pathogen typing is fundamental for characterizing pathogen biology and understanding their dispersion patterns (Achtman 2008; Bergsma-Vlami et al. 2012; Cesbron et al. 2014), population dynamics (Achtman 2008; Poulin et al. 2015), genetic diversity (Poulin et al. 2015), and pathogen outbreaks and for establishing relatedness among strains. Using this information, different disease control strategies can be proposed, thereby ensuring sustainable crop production (Cesbron et al. 2014; Restrepo et al. 1999a). Robust tools targeting appropriate molecular markers are necessary for the identification and differentiation of plant pathogen populations

${ }^{\dagger}$ Corresponding author: A. Bernal; E-mail: abernal@uniandes.edu.co

Funding: Financial support was provided by the Faculty of Sciences from Universidad de los Andes-Bogotá, Colombia (call numbers 2014-10 and 2015-20) and the UMR Interactions Plantes Microorganismes Environement and the Agropolis Foundation (project PAIX), Montpellier, France (grant number 1403073). The ECOS Nord programme supported inter-laboratory mobility (grant number C15A01). L. Rache was supported by Departamento Administrativo de Ciencia, Tecnología e Innovación-Colciencias with a doctoral fellowship (call number 528, 2011).

C. Vernière and A. Bernal contributed equally to this work.

*The $\boldsymbol{e}$-Xtra logo stands for "electronic extra" and indicates that one supplementary figure and four supplementary tables are published online.

The author(s) declare no conflict of interest.

C 2019 The American Phytopathological Society
(Boudon et al. 2005; Cesbron et al. 2014; Li et al. 2009; Poulin et al. 2015; Restrepo et al. 1999a).

Several technical limitations exist for different molecular markers. Systems producing banding patterns and lacking interlaboratory reproducibility (restriction fragment length polymorphisms [RFLPs], repetitive-element palindromic polymerase chain reaction [rep-PCR], randomly amplified polymorphic DNA [RAPD], and amplified fragment length polymorphisms [AFLPs]) do not facilitate data exchange. High-quality DNA is necessary to analyze digestion-based patterns (RFLP and AFLP), and some techniques are time consuming (RFLP). On the other hand, singlenucleotide polymorphisms (SNPs) and multilocus sequence typing (MLST) present very low levels of sequence diversity which prevent their use with genetically monomorphic bacteria (Achtman 2008).

Multiple loci variable number of tandem repeat analysis (MLVA) has been proposed as a highly discriminant tool for tracking bacterial outbreaks (Lindstedt 2005; Van Belkum 2007). MLVA targets several tandem repeat (TR) regions whose number of repeat units per locus may vary between isolates of the same species, thus producing variable numbers of TRs (VNTRs). The first MLVA scheme adapted to a bacterial plant pathogen was developed for Xylella fastidiosa (Coletta-Filho et al. 2001). Studies of population diversity of plant-pathogenic bacteria using MLVA have increased remarkably, particularly because bacterial whole-genome sequencing has increased (Arrieta-Ortiz et al. 2013; Bühlmann et al. 2014; Cesbron et al. 2014; Chenal-Francisque et al. 2013; Leduc et al. 2015; Mansfield et al. 2012; Poulin et al. 2015; Pruvost et al. 2014; U'Ren et al. 2007; Zaluga et al. 2013). This method allows 
questions about the epidemiology and management of diseases to be answered, and is user friendly (Vernière et al. 2014; Zaluga et al. 2013). The main advantages of using VNTRs over other bacterial genotyping methods are the ease of technique standardization, the short time needed to evaluate a large number of isolates, the accessibility of equipment and materials, and the high resolution (Lindstedt 2005; Trujillo et al. 2014a). The only identified disadvantage is that homoplasy can bias the estimation of genetic diversity from VNTR; however, this bias can be controlled using a high number of VNTRs.

Xanthomonas axonopodis pv. manihotis, which was recently renamed X. phaseoli pv. manihotis (Constantin et al. 2016; Oren and Garrity 2016), causes bacterial blight, which is the most important bacterial disease that affects cassava crops (Abaca et al. 2014; Bernal et al. 2011). X. phaseoli pv. manihotis is a Gram-negative bacterium without pigmentation (Lozano 1986; Ogunjobi et al. 2008) that causes different symptoms depending on the disease severity. Initially, bacteria enter plant cells through open wounds or stomata and colonize the mesophyll, causing angular spots (Lozano and Sequeira 1974). Subsequently, in susceptible plants, X. phaseoli pv. manihotis populations colonize the vascular tissue, thereby interrupting the flow of nutrients and water and inducing severe symptoms such as stem wilt and dieback (Arrieta-Ortiz et al. 2013; Mansfield et al. 2012). Cassava is propagated through cuttings from the stems that consequently can be contaminated and constitute a source of disease dispersal. Cassava bacterial blight (CBB) is widespread in South America, Africa, and Asia (Boher and Verdier 1994; Lozano and Sequeira 1974). Globally, bacterial blight generates losses between 50 and $75 \%$ when environmental conditions are conducive for the disease (Lozano 1986; Wydra and Verdier 2002). Furthermore, a reduction in crop productivity decreases the availability of vegetative propagation material for cassava cultivation (Fanou et al. 2018; Lozano 1986).

Currently, the disease is controlled through cultural practices and the use of resistant varieties. Cultural practices used to control CBB include the use of pathogen-free cuttings; elimination of inoculum reservoirs such as weeds, crop debris, or plant cuttings; crop rotation; and maintenance of appropriate soil fertility. Perhaps the most important cultural measure is the use of pathogen-free cuttings obtained after treatment with chemical compounds and those from fields where the pathogen is absent (López et al. 2007; Lozano 1986). The use of resistant cassava varieties is desirable (Lozano 1986) but plant resistance may break down due to the appearance of new variants within the pathogen population (Lozano 1986; Yan et al. 2013). These variants can cause shifts in pathogen populations that can result, for example, from loss of recognition by resistant varieties, hence providing an adaptative advantage to these strains (Vera Cruz et al. 2000). Therefore, continuous assessment of $X$. phaseoli pv. manihotis population variation worldwide is important to screen for resistant varieties and propose appropriate and targeted control measures for the disease (Vera Cruz et al. 2000; Yan et al. 2013). Several studies have been performed to monitor $X$. phaseoli pv. manihotis population structures in countries such as Nigeria (Ogunjobi et al. 2006, 2010), Venezuela (Verdier et al. 1998), Colombia (Restrepo and Verdier 1997; Restrepo et al. 1999a, 2000, 2004; Trujillo et al. 2014a,b), and Brazil (Restrepo et al. 1999 b), where the disease is a major constraint. However, these studies have been sporadic in time and space.

Genetic diversity studies of $X$. phaseoli pv. manihotis have been performed using different molecular markers such as RFLP targeting the 16S ribosomal RNA gene and repetitive chromosomal regions (probes pBS6 and pBS8) (Verdier et al. 1993), the pathogenicity factor $p t h B$ (probe $p t h \mathrm{~B}$ ), or repetitive regions (pBS6 and pBS8) (Restrepo and Verdier 1997; Verdier et al. 1993). RAPD and AFLP were used to characterize strains isolated from west and southeast Africa (Ogunjobi et al. 2010, 2006).

In Colombia, several markers have been used at different times, with the latest being VNTRs (Restrepo and Verdier 1997; Restrepo et al. 1999a; Trujillo et al. 2014a,b). X. phaseoli pv. manihotis haplotypes identified recently in the Colombian Caribbean region differed from those found in the 1990s, although some haplotypes were genetically related. Historically, the main driver of diversity has been the migration of strains (Trujillo et al. 2014b). The locality of Chinú was found to be a center of diversity for the Caribbean coast. In this locality, a high number of haplotypes, high diversity indices, and low genetic distances between haplotypes were identified (Trujillo et al. 2014b).

The genome sequence of Colombian strain $X$. phaseoli pv. manihotis CIO151 (https://iant.toulouse.inra.fr/bacteria/annotation/cgi/xanmn/xanmn.cgi) (Arrieta-Ortiz et al. 2013) and $65 \mathrm{draft}$ genome sequences (Bart et al. 2012) were used to develop genomebased molecular typing tools. Arrieta-Ortiz et al. (2013) identified and selected 60 VNTR loci from $X$. phaseoli pv. manihotis strains representing global diversity. Among these 60 loci, 14 microsatellites were polymorphic and could be used to characterize $X$. phaseoli pv. manihotis populations worldwide (Arrieta-Ortiz et al. 2013). Trujillo et al. (2014a) assessed the usefulness of VNTR loci by selecting five of the most discriminant TRs (four microsatellites and one minisatellite) using $X$. phaseoli pv. manihotis strains collected from the Colombian Eastern Plains. However, the number of VNTRs in this scheme was low compared with the number used for other xanthomonads (Bui Thi Ngoc et al. 2009b; Cesbron et al. 2014; Poulin et al. 2015; Pruvost et al. 2014; Vernière et al. 2014; Zhao et al. 2012), leading to possible issues in homoplasy and underestimation of diversity.

All genetic diversity studies performed with $X$. phaseoli $\mathrm{pv}$. manihotis worldwide highlight the importance of continuous monitoring of $X$. phaseoli pv. manihotis population variability. A better understanding of the spatiotemporal dynamics of the bacterial populations at small scales is necessary to evaluate or propose adapted strategies to control CBB (Ogunjobi et al. 2010; Trujillo et al. 2014b; Vera Cruz et al. 2000; Verdier et al. 1998). Thus, the aims of this study were to (i) develop an improved MLVA scheme targeting 15 VNTR loci (MLVA-15) for the study of $X$. phaseoli pv. manihotis populations on a local or regional scale and (ii) evaluate the MLVA-15 scheme by analyzing $X$. phaseoli pv. manihotis genetic diversity in the Colombian Caribbean region.

\section{MATERIALS AND METHODS}

Bacterial strains and DNA extraction. To analyze the genetic diversity of $X$. phaseoli pv. manihotis in the Colombian Caribbean region, $99 X$. phaseoli pv. manihotis strains isolated between 2008 and 2015 were characterized (Supplementary Table S1). Fifty-five of these strains were isolated between 2008 and 2010 and previously typed using AFLPs by Trujillo et al. (2014b). Fortyfour additional isolates were collected for this study between 2013 and 2015 from three localities in the Caribbean region: Chinú $(\mathrm{N}$ $\left.09.064^{\circ}, \mathrm{W} 075.489^{\circ}\right)$, Ciénaga de Oro (N $08.889^{\circ}$, W $075.569^{\circ}$ ), and San Jacinto (N $09.835^{\circ}$, W $075.121^{\circ}$ ) (Fig. 1). These localities were also previously sampled by Trujillo et al. (2014b). The field sampling was performed randomly depending on the incidence of the disease, and symptomatic leaves were collected as reported by Trujillo et al. (2014a,b). The localities were visited once per year in November, and two to seven fields were sampled in each locality. One strain with a sequenced genome, CIO151 (Arrieta-Ortiz et al. 2013), was used as a control in each typing assay.

Bacteria were isolated as described by Trujillo et al. (2014b) using LPGA medium ( $5 \mathrm{~g}$ of dextrose, $5 \mathrm{~g}$ of yeast extract, $5 \mathrm{~g}$ of peptone, and $15 \mathrm{~g}$ of agar in 1 liter of distilled water) and incubated at $28^{\circ} \mathrm{C}$. White, bright, and viscous single colonies were cultured into sterile Phi medium ( $1 \mathrm{~g}$ of yeast extract, $10 \mathrm{~g}$ of peptone, and $1 \mathrm{~g}$ of casamino acids per liter of distilled water) and incubated at $28^{\circ} \mathrm{C}$ overnight with shaker agitation. In total, $50 \mu \mathrm{l}$ of liquid medium was boiled and used as a template for the diagnostic multiplex PCR using primers complementary to a conserved region in a 
pathogenicity factor (Castiblanco et al. 2013) of X. phaseoli pv. manihotis and the RNA polymerase $\beta$ subunit (rpoB gene) (BernalGaleano et al. 2018). Both genes were successfully amplified from the isolates and conserved in $30 \%$ glycerol at $-80^{\circ} \mathrm{C}$.

For DNA extraction, single colonies of $X$. phaseoli pv. manihotis were inoculated in Phi medium and grown overnight, and $1 \mathrm{ml}$ of bacterial culture was used to extract genomic DNA. The extraction was performed using the commercial Invitrogen PureLink Genomic DNA kit (Invitrogen, Carlsbad, CA, U.S.A.) according to the manufacturer's instructions. The DNA was quantified using the NanoDrop spectrophotometer ND1000 and agarose gel electrophoresis $(1 \%)$ and stored at $-20^{\circ} \mathrm{C}$.

Development of the MLVA scheme. To predict and analyze the VNTR loci, $12 X$. phaseoli pv. manihotis genomes representative of global diversity were selected based on the genome sequence quality (lower number of contigs). These strains consisted of eight from Brazil, two from Colombia, and two from Uganda (Supplementary Table S2). The genome analysis was conducted using the Xanthomonas utilities website (http://www.biopred.net/ VNTR/). The genomes were screened for VNTRs using the following parameters: total length between 30 and 1,000 bp, unit length of 5 to $9 \mathrm{bp}$, copy number of at least 6 , and similarity of repeats within arrays between 80 and $100 \%$. This set of genomes was selected because they were the least fragmented among the 65 genomes available. However, some TRs are absent in these strains because they are not complete genomes.

The TR loci were grouped into pools of four loci for the multiplex PCR. Then, primers were designed for the VNTR arrays at different distances to avoid overlap between amplicon sizes. The flanking regions were aligned using MUSCLE (https://www.ebi.ac.uk/ Tools $/ \mathrm{msa} / \mathrm{muscle} /$ ). Primers were designed with the following parameters: 20 nucleotides in length; 55 to $70 \% \mathrm{G}+\mathrm{C}$ content; and temperature of $70 \pm 1^{\circ} \mathrm{C}$ at a $0.2 \mu \mathrm{M}$ primer concentration and $50 \mathrm{mM}$ salt concentration (https://www.thermofisher.com/ us/en/home/brands/thermo-scientific/molecular-biology/molecularbiology-learning-center/molecular-biology-resource-library/thermoscientific-web-tools/multiple-primer-analyzer.html\#/legacy=www. thermoscientificbio.com). The scheme was subsequently optimized by performing an in silico analysis of amplicons and multiple sequence analyses with all $65 \mathrm{X}$. phaseoli pv. manihotis genomes available.

The primers were individually tested using DNA from a set of $X$. phaseoli pv. manihotis strains representative of the genetic diversity in the Colombian Eastern Plains. The primers were subsequently tested in pools of four pairs, and the amplicons were visualized with agarose gel electrophoresis (2\%). The PCR contained $0.4 \mathrm{mM}$ each $\mathrm{dNTP}, 1 \times$ DreamTaq buffer, 0.2 to $0.4 \mu \mathrm{M}$ each primer, DreamTaq DNA polymerase (Thermo Fisher Scientific Inc., Waltham, MA, U.S.A.) at $0.025 \mathrm{U} / \mu \mathrm{l}$, and DNA at $30 \mathrm{ng} / \mu \mathrm{l}$ in a total volume of $10 \mu \mathrm{l}$. The multiplex PCR conditions were as follows: predenaturation at $95^{\circ} \mathrm{C}$ for $5 \mathrm{~min} ; 30$ cycles of denaturation at $95^{\circ} \mathrm{C}$ for $30 \mathrm{~s}$, an annealing temperature specific for each pool for $40 \mathrm{~s}$ (Table 1), and extension at $72^{\circ} \mathrm{C}$ for $2 \mathrm{~min}$; and a final extension at $72^{\circ} \mathrm{C}$ for $5 \mathrm{~min}$.

Once the primer design and quality were verified, they were labeled with a fluorescent dye at their $5^{\prime}$ ends (6-carboxyfluorescein [6-FAM] or JOE) (Table 1). The amplicons for capillary electrophoresis were first diluted 5, 10, 15- or 20-fold for standardization of PCR products and then prepared as follows: $9 \mu \mathrm{l}$ of HiDi formamide (Applied Biosystems Inc., Foster City, CA, U.S.A.), $0.5 \mu \mathrm{l}$ of GeneScan 500 ROX internal size standard (Applied Biosystems), and $1 \mu \mathrm{l}$ of previously diluted multiplex PCR amplicons. Capillary electrophoresis was conducted in an ABI 3500 Genetic Analyzer (Applied Biosystems) at Universidad de los Andes in Colombia. The amplicons sizes were determined using the GeneMapper (Applied Biosystems) software, version 4.1. $X$. phaseoli pv. manihotis strain CIO151 was used as a reference in each experiment.
The reproducibility of the technique was verified by replicating the analysis on seven representative $X$. phaseoli pv. manihotis strains in another laboratory (Labex Centre Méditerranéen Environnement Biodiversité and Institut des Sciences de l'Evolution, Montpellier, France). For this purpose, the PCR was performed using primers labeled with four different fluorescent dyes (6-FAM, NED, PET, and VIC) (Applied Biosystems) (Table 1) and detected by capillary electrophoresis in an ABI 3500 Genetic Analyzer.

Specificity of the MLVA-15 typing system. Specificity was assessed by amplification of all TR loci on other strains of $X$. phaseoli pv. manihotis, X. phaseoli pv. phaseoli, and other Xanthomonas spp. (Supplementary Table S4). The taxonomic names were retained from previous reports (Constantin et al. 2016; Young et al. 2008). Template DNA was obtained by bacterial growth for 18 to $24 \mathrm{~h}$ on a culture of yeast-peptone-glucose agar (yeast extract at $7 \mathrm{~g}$ liter $^{-1}$, peptone at $7 \mathrm{~g} \mathrm{liter}^{-1}$, glucose at $7 \mathrm{~g} \mathrm{liter}^{-1}$ agar

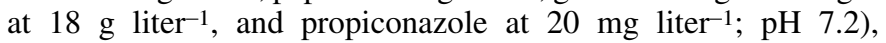
centrifugation, resuspension in water and subsequent boiling. This suspension $(1 \mu \mathrm{l})$ was used for PCR. PCR conditions described above for $X$. phaseoli pv. manihotis were used.

Characterization of $X$. phaseoli pv. manihotis populations using the MLVA typing scheme. The discriminatory power of the MLVA scheme was evaluated using the 2008-to-2010 collection of $X$. phaseoli pv. manihotis strains $(n=55)$ from Colombia, which were previously collected and analyzed by Trujillo et al. (2014b). This collection was typed using AFLP markers. The Hunter-Gaston discriminatory index (HGDI) (Hunter and Gaston 1988), multilocus genotype, and polymorphic loci were calculated for each type of molecular marker using the Poppr (Grünwald et al. 2015) and Arlequin software (Excoffier et al. 2005).

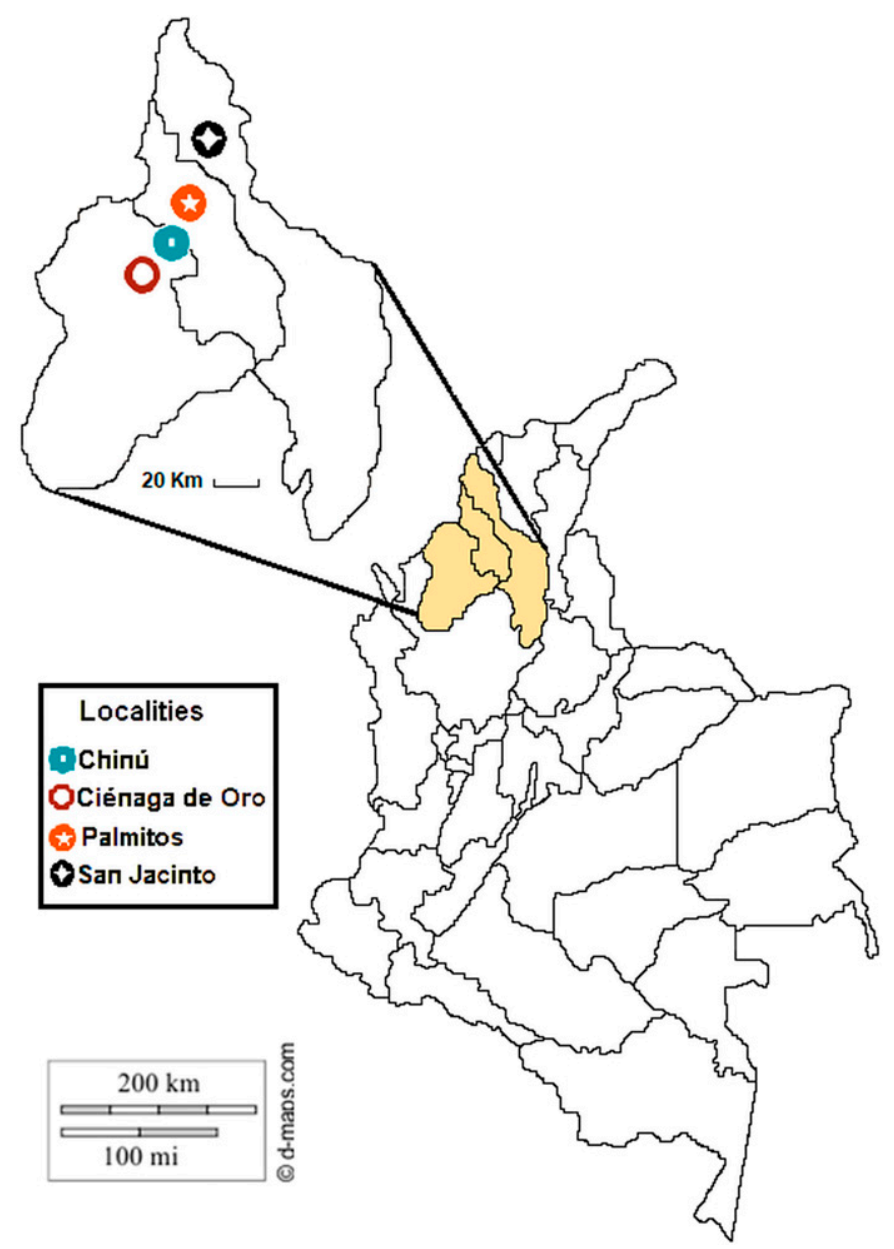

Fig. 1. Localities and sampling sites in the Colombian Caribbean region. 
The correlations between genetic distance matrices were assessed using the Mantel test of matrix correspondence (Mantel 1967). Genetic distance metrics were constructed as indicated for codominant and dominant markers (Maguire et al. 2002). All Mantel tests were performed using GENALEX 6.5 software (Peakall and Smouse 2012). Statistical significance was determined by random permutation $(n=999)$. A second collection of $X$. phaseoli $\mathrm{pv}$. manihotis originating from Argentina was typed to evaluate the discriminative power at a regional level.

The genotyping resolution of the MLVA-15 scheme at a regional scale was evaluated for the complete strain collection $(n=99)$, which was established over a 7-year period. A genotype accumulation curve was drawn with the Poppr 2.2.1 package in $R$ (Grünwald et al. 2015) to test whether the number of loci used allowed accurate determination of the number of haplotypes in the sample. A permutation procedure $(n=1,000)$ was realized for each class of loci.

Reconstruction of the haplotype network. The genetic relationships among the $X$. phaseoli pv. manihotis strains in the 2008-to-2015 collection $(n=99)$ were displayed with a minimum spanning tree using the PHYLOViZ 2.0 software (Francisco et al. 2012). The haplotypes were connected using an algorithm combining global optimal eBURST and Euclidian distances (Francisco et al. 2012). Clonal complexes were identified as groups of single-locus variants (SLVs) (i.e., haplotypes with 14 identical alleles differing in a single TR locus). The evolutionary model for each locus was explored by estimating the repeat number profile among the different haplotypes along the evolutionary pathway

TABLE 1. Multiplex scheme of primer pairs in each pool, tandem repeat sequence, and MLVA-15 microsatellite scheme description ${ }^{\mathrm{a}}$

\begin{tabular}{|c|c|c|c|c|c|c|c|c|c|c|c|c|}
\hline \multirow[b]{2}{*}{ Pool } & \multirow[b]{2}{*}{ VNTR locus } & \multirow{2}{*}{$\begin{array}{l}\text { VNTR locus } \\
\text { nomenclature }\end{array}$} & \multirow[b]{2}{*}{ Primers sequence } & \multicolumn{2}{|c|}{ Label $^{\mathrm{b}}$} & \multirow[b]{2}{*}{$\mathrm{AT}^{\mathrm{c}}$} & \multicolumn{3}{|c|}{ Amplicon length } & \multirow{2}{*}{$\begin{array}{l}\text { Allelic } \\
\text { range }^{\mathrm{d}}\end{array}$} & \multirow{2}{*}{$\begin{array}{l}\text { VNTR sequence } \\
\text { of the reference } \\
\text { strain }\end{array}$} & \multirow[b]{2}{*}{$\mathrm{HGDI}^{\mathrm{e}}$} \\
\hline & & & & 1 & 2 & & Tested strains ${ }^{\mathrm{d}}$ & Ref strain & 65 genomes & & & \\
\hline \multirow[t]{6}{*}{1} & Xpm1-37 & $\cdots$ & CGACATCAGCAGGTGGCGAC & JOE & $\cdots$ & $\cdots$ & $144-198$ & 233 & $134-181$ & $5-13$ & $\begin{array}{l}\text { CGATTCC(7) CGAATCC }(2) \\
\text { CGATTCC(2) CGAATCC(6) } \\
\text { CGAATCA(1) }\end{array}$ & 0.66 \\
\hline & & & CGACGCAGAGACAGGCGATG & & PET & & & & & & & \\
\hline & $\mathrm{Xpm} 1-08^{\mathrm{f}}$ & $\mathrm{XaG} 2 \_106^{\mathrm{g}}$ & CGACGTTTCATCGCGAGCAG & 6-FAM & $\ldots$ & 61 & $191-246$ & 349 & $173-250$ & $14-22$ & $\begin{array}{l}\text { GGATTTG(2) GGGATTT(18) } \\
\text { GGGGATT(15) GGGGAAT(1) } \\
\text { CGGGAAT(1) }\end{array}$ & 0.74 \\
\hline & & $\ldots$ & CAGCGAGCGTCTCGTCCTCA & & VIC & $\ldots$ & & $\ldots$ & & $\ldots$ & & $\ldots$ \\
\hline & Xpm1-15 & $\cdots$ & GTCTTGGCCTTGGCCCACAG & JOE & $\cdots$ & 61 & $288-387$ & 346 & $281-351$ & $8-22$ & $\begin{array}{l}\text { ACTCCCC(1) ATTCCCC(7) } \\
\text { ATTCCCG(5) AATCCCG(3) }\end{array}$ & 0.85 \\
\hline & & $\ldots$ & ACAAGGCCGAGGGTGAGCAG & & NED & $\cdots$ & & & & & & \\
\hline \multirow[t]{8}{*}{2} & Xpm1-18 & $\cdots$ & GTCCATCCTTGGCGCGACCT & 6-FAM & $\cdots$ & 60 & $182-230$ & 189 & $174-232$ & $7-14$ & $\begin{array}{l}\text { TTCGGGA(4) ATCGGGA(3) } \\
\text { ATCGTCA(1) }\end{array}$ & 0.69 \\
\hline & & $\cdots$ & CAAGAGCGCCCGGTTGAAAA & $\ldots$ & 6-FAM & $\ldots$ & & $\ldots$ & 174020 & 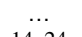 & & $0=0$ \\
\hline & $\mathrm{Xpm} 1-21^{\mathrm{f}}$ & XaG1_70 & GGGAGAAGGACGCGGACTGC & JOE & $\cdots$ & 60 & $188-260$ & 189 & $174-220$ & $14-24$ & $\begin{array}{l}\text { AATCCGC(6) AGTCCGC(1) } \\
\text { AATCCGC(1) AATCCCC(4) } \\
\text { GCTTCAC(2) }\end{array}$ & 0.52 \\
\hline & $\ldots$ & $\ldots$ & GCGAGCAGGTGCAATCGGTT & $\ldots$ & NED & $\ldots$ & $\ldots$ & $\ldots$ & $\ldots$ & $\ldots$ & $\ldots$ & $\ldots$ \\
\hline & Xpm1-31 & $\cdots$ & TCGCAACCGCGATACGCTTT & 6-FAM & $\cdots$ & 60 & $102-138$ & 146 & $106-149$ & $5-10$ & $\begin{array}{l}\text { GATTCCC(7) GAATCCC(1) } \\
\text { GATTCCC(1) GAATCCC(2) }\end{array}$ & 0.37 \\
\hline & & $\ldots$ & GTTCACGCTGGATCAGCCGG & & PET & & & & & & & \\
\hline & Xpm1-35 & $\ldots$ & GGCGTTTTTCGGTGGGAAGC & 6-FAM & $\ldots$ & 60 & $360-407$ & 387 & $319-371$ & $19-26$ & $\begin{array}{l}\text { TTCGGGA(6) ATCGGGA(10) } \\
\text { GTCGGGA(2) GTCGGAA(1) } \\
\text { GTCGGGA(1) ATCGGGA(2) } \\
\text { ATCGGAA(1) }\end{array}$ & 0.72 \\
\hline & $\cdots$ & $\cdots$ & CTGAGCAACGCACGGCTCAG & $\ldots$ & VIC & $\cdots$ & $\cdots$ & $\ldots$ & $\ldots$ & $\ldots$ & $\cdots$ & $\ldots$ \\
\hline \multirow[t]{4}{*}{3} & Xpm1-06 & $\ldots$ & GCGATAGGCCGAGGTCACCA & 6-FAM & $\cdots$ & 61 & $185-221$ & 192 & $187-222$ & $9-14$ & $\begin{array}{c}\text { AATCGGG(1) AATGGGG(2) } \\
\text { AATCGGG(1) AATCGAG(1) } \\
\text { ATTCGAG(1) ATTTGGG(1) } \\
\text { AGTCGGG(2) AGTCGTT(1) }\end{array}$ & 0.08 \\
\hline & Xpm1- $07^{\mathrm{f}}$ & $\begin{array}{c}\ldots \\
\text { XaG1_65 } \\
\quad \ldots\end{array}$ & $\begin{array}{l}\text { CCGGCGTGCATAGATGATGC } \\
\text { ACTGCCACTCGTGCGAGCAC } \\
\text { TGATGTTCGGCAGTGGCGAT }\end{array}$ & $\begin{array}{c}\ldots \\
6-\mathrm{FAM} \\
\ldots\end{array}$ & $\begin{array}{l}\text { 6-FAM } \\
\ldots \\
\text { NED }\end{array}$ & $\begin{array}{l}\cdots \\
61 \\
\cdots\end{array}$ & $\begin{array}{c}\ldots \\
82-118 \\
\ldots\end{array}$ & $\begin{array}{l}\ldots \\
83\end{array}$ & $\begin{array}{c}\ldots \\
92-122 \\
\ldots\end{array}$ & $\stackrel{\ldots}{6-12}$ & GGTGTG(2) GGTGTC(4) & 0.69 \\
\hline & $\begin{array}{c}\mathrm{Xpm} 1-20^{\mathrm{f}} \\
\ldots\end{array}$ & $\begin{array}{c}\text { XaG1_71 } \\
\ldots\end{array}$ & $\begin{array}{l}\text { GGCAGGGTTGCAGCCTGAGA } \\
\text { TCGACGATCTGCGGTTCGAC }\end{array}$ & $\begin{array}{c}\text { 6-FAM } \\
\quad \ldots\end{array}$ & $\begin{array}{c}\ldots \\
\text { PET }\end{array}$ & $\begin{array}{l}61 \\
\cdots\end{array}$ & $\begin{array}{c}278-326 \\
\ldots\end{array}$ & $\begin{array}{c}296 \\
\ldots\end{array}$ & $\begin{array}{c}276-329 \\
\ldots\end{array}$ & $\begin{array}{l}4-12 \\
\ldots\end{array}$ & $\operatorname{GCACCG}(7)$ & $\begin{array}{c}0.34 \\
\ldots\end{array}$ \\
\hline & $\mathrm{Xpm} 1-38^{\mathrm{f}}$ & XaG1_58g & TTGCGGACGCTATGGGGAAC & JOE & $\ldots$ & 61 & $179-203$ & 197 & $172-208$ & $7-11$ & $\begin{array}{l}\text { CCCACT(6) CCCACA(1) } \\
\text { CCAACG(1) CCGACG(2) }\end{array}$ & 0.57 \\
\hline \multirow[t]{6}{*}{4} & $\begin{array}{c}\cdots \\
\mathrm{Xpm} 1-19^{\mathrm{h}}\end{array}$ & XaG1_67 & $\begin{array}{l}\text { TATTGGTGACCTGCACGCGG } \\
\text { GCGGCGAACAGCAGTAGCGT }\end{array}$ & 6-FAM & $\begin{array}{r}\text { VIC } \\
\ldots\end{array}$ & $\begin{array}{ll}\ldots \\
61\end{array}$ & $\begin{array}{c}\cdots \\
211-252\end{array}$ & $\begin{array}{c}\ldots \\
234\end{array}$ & $\begin{array}{c}\cdots \\
195-276\end{array}$ & $15-22$ & $\begin{array}{l}\text { TCGGTA(5) TCGGTG(3) } \\
\text { TCGGCG(2) TCGGTG(8) } \\
\text { TCGGCG(1) }\end{array}$ & $\begin{array}{c}\ldots \\
0.76\end{array}$ \\
\hline & .. & $\ldots$ & CCAGCAATCACCCGTCCGTC & $\ldots$ & 6-FAM & $\ldots$ & & $\ldots$ & & $\ldots$ & $\ldots$ & $\ldots$ \\
\hline & $\begin{array}{c}\text { Xpm1-25 } \\
\ldots\end{array}$ & $\begin{array}{c}\text { XaG1_73 } \\
\ldots\end{array}$ & $\begin{array}{l}\text { ATGCTCACTCCCACGGGCAT } \\
\text { ACCACCGGTGCGTCCATCTC }\end{array}$ & $\begin{array}{c}\text { 6-FAM } \\
\ldots\end{array}$ & $\begin{aligned} \ldots \\
\text { NED }\end{aligned}$ & $\begin{array}{l}61 \\
\ldots\end{array}$ & $\begin{array}{c}298-366 \\
\ldots\end{array}$ & $\begin{array}{c}324 \\
\ldots\end{array}$ & $\begin{array}{c}304-382 \\
\ldots\end{array}$ & $\begin{array}{l}3-14 \\
\ldots\end{array}$ & GGTCAT(7) & $\begin{array}{c}0.41 \\
\ldots\end{array}$ \\
\hline & $\mathrm{Xpm} 1-27^{\mathrm{h}}$ & XaG1_02 ${ }^{\mathrm{i}}$ & ATCAAGGTATCGCGGCTGGC & JOE & $\ldots$ & 61 & $221-291$ & 215 & 190-293 & $10-20$ & $\begin{array}{l}\text { GGGGAAT(4) GGGGAAG(1) } \\
\text { CGGGAAG(4) }\end{array}$ & 0.83 \\
\hline & $\begin{array}{c}\cdots \\
\mathrm{Xpm} 1-30^{\mathrm{h}}\end{array}$ & XaG1_29i & $\begin{array}{l}\text { AATGCATCGGCATCGCCAAC } \\
\text { GCCGTGGGCGAATACGCTTC }\end{array}$ & 6-FAM & $\begin{array}{r}\text { PET } \\
\quad \cdots\end{array}$ & $\begin{array}{l}\ldots \\
61\end{array}$ & $\begin{array}{c}\cdots \\
117-183\end{array}$ & $\ldots$ & $\begin{array}{c}\cdots \\
127-211\end{array}$ & $\begin{array}{l}\ldots \\
9-18\end{array}$ & $\begin{array}{l}\ldots \\
\text { CGTCATC(4) CGCCAAT(1) } \\
\text { CCCGAAT(1) TCCGAAT(5) } \\
\text { CCCGAAT(2) }\end{array}$ & $\begin{array}{c}\cdots \\
0.68\end{array}$ \\
\hline & $\cdots$ & $\cdots$ & CTGAAGATCGGGCCACGCAG & $\cdots$ & VIC & $\cdots$ & $\ldots$ & $\cdots$ & $\cdots$ & $\cdots$ & $\ldots$ & $\cdots$ \\
\hline
\end{tabular}

a The multiple loci variable number of tandem repeat analysis (MLVA)-15 scheme comprises 15 variable number of tandem repeat (VNTR) loci.

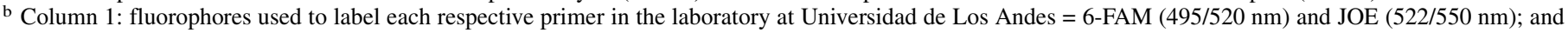
column 2 = fluorophores used to label each respective primer in the laboratory at IRD, Montpellier: 6-FAM (495/520 nm), VIC (524/557 nm), NED (560/575 $\mathrm{nm})$, and PET (570/591 nm).

c Annealing temperature of primers.

d Application on 99 X. phaseoli pv. manihotis strains from the Caribbean region of Colombia.

e Hunter-Gaston discriminatory index using the 99 X. phaseoli pv. manihotis strains.

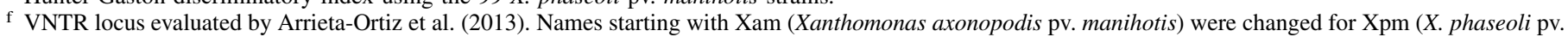
manihotis).

g VNTR locus nomenclature from Arrieta-Ortiz et al. (2013).

h VNTR locus evaluated by Trujillo et al. (2014b).

i VNTR locus nomenclature from Trujillo et al. (2014b). 
within clonal complexes (i.e., SLVs). Genetic differentiation was calculated using the Arlequin software (Excoffier et al. 2005).

\section{RESULTS}

Fifteen loci met all criteria for development of an MLVA scheme for the $X$. phaseoli pv. manihotis population diversity analysis. The VNTR loci obtained after screening the $12 X$. phaseoli pv. manihotis genomes with the highest quality available at the National Center for Biotechnology Information (NCBI) GenBank were selected based on the following characteristics: loci were associated with at least $500 \mathrm{bp}$ of flanking sequences on both sides, their repeat unit lengths ranged from 5 to $8 \mathrm{bp}$, repeat arrays consisted of at least six repeats, and the loci had high HGDIs estimated using these 12 genomes. In total, 64 candidate VNTRs met these characteristics. Of these candidates, 18 loci with an HGDI $>0.6$ were retained. One locus was eliminated because it consisted of 3-bp TRs included in a hexanucleotide motif; a second locus was eliminated because it had highly variable repeat sequences in further analyses of 99 strains from Colombia (see below); a third locus was eliminated later because it was found at the end of the sequence contig in the majority of the 65 genomes available for $X$. phaseoli pv. manihotis in NCBI. As a result, 15 loci were selected for the MLVA scheme. The HGDI varied between 0.654 and 0.924 (Table 2). Of the 15 loci, 9 were evaluated previously by Arrieta-Ortiz et al. (2013) using strains representative of worldwide diversity. Four of these nine loci were used by Trujillo et al. (2014a) to assess the diversity of $X$. phaseoli pv. manihotis in the Colombian Eastern Plains. Analysis of 12 and $65 X$. phaseoli pv. manihotis genomes showed that the unit length of the 15 TR loci varied between 6 and $7 \mathrm{bp}$, while the copy number ranged between 6 and 25 for the 12 genomes and 3 and 25 for the 65 genomes (Table 3). Flanking regions of all selected loci were conserved among the analyzed genomes. For a few loci, the flanking regions were only available in 11,10 , or 9 of the 12 genomes due to the fragmented nature of the genome sequences (Table 2). Data were not verified by Sanger sequencing from these strains.
Almost all TR loci in this scheme are imperfect loci. Only Xpm125 is a perfect locus that exclusively consists of identical copies of the repeat units. This was confirmed by Sanger sequencing of the amplicons obtained from strain CIO151 (Table 1). The six newly characterized TR loci in this scheme are located within coding sequences; namely, a conserved hypothetical protein (Xpm1-35 and Xpm1-37), a molybdopterin biosynthesis protein (Xpm1-6), a putative type III effector (Xpm1-31), a chaperone protein (Xpm115 ), and a putative $\mathrm{Na}^{+}$extrusion $\mathrm{ABC}$ transporter (Xpm1-18).

The primer quality and design were tested individually using DNA from $10 X$. phaseoli $\mathrm{pv}$. manihotis strains representative of the genetic diversity in the Colombian Eastern Plains (Supplementary Fig. 1). In all cases, unique DNA amplicons of the expected size were observed following agarose gel electrophoresis but the amplicons were not confirmed by Sanger sequencing. Subsequently, multiplex PCR with labeled primers was performed, and $20 \times$ dilutions of the amplicons were used for capillary electrophoresis.

The 15 TR loci were grouped into four pools of VNTR markers, with three pools comprising four loci and one pool comprising three loci (Table 1). In the pools comprising four loci, the expected sizes of the amplicons in each pool were sufficiently different that three loci labeled could be labeled with the same fluorophore and avoid overlap of the amplicon size ranges. The remaining amplicon in each pool was labeled with a different fluorophore to differentiate it by using capillary electrophoresis. In the pool comprising three loci, the expected sizes of the amplicons were sufficiently different for unambiguous assignments.

The reproducibility of this scheme was evaluated using different fluorescent dyes on the same Genetic Analyzer model in different laboratories in France and Colombia. We obtained similar amplicon sizes producing exactly the same allelic profiles, showing that the technique had high reproducibility and could be used in different laboratories to analyze the $X$. phaseoli pv. manihotis population genetic diversity worldwide. The use of $X$. phaseoli pv. manihotis strain CIO151 as a positive control and reference strain (Restrepo and Verdier 1997) is helpful for calculating the number of repeats for each analyzed strain (Table 1). The amplicon length range for

TABLE 2. Characteristics of the loci selected for the multiple loci variable number of tandem repeat (VNTR) analysis scheme from 12 Xanthomonas phaseoli pv. manihotis genomes

\begin{tabular}{|c|c|c|c|c|c|c|c|c|}
\hline \multirow[b]{2}{*}{ Locus $^{b}$} & \multirow[b]{2}{*}{ Repeat regions $^{\mathrm{c}}$} & \multirow[b]{2}{*}{ Accession number for CIO1 strain } & \multicolumn{2}{|c|}{$\begin{array}{l}\text { Genome location } \\
\text { CIO151 strain }\end{array}$} & \multirow[b]{2}{*}{$\mathrm{FS}^{\mathrm{d}}$} & \multirow[b]{2}{*}{ Unit $^{\mathrm{e}}$} & \multirow[b]{2}{*}{$\mathrm{CN}^{\mathrm{f}}$} & \multirow[b]{2}{*}{ HGDI $^{\mathrm{g}}$} \\
\hline & & & Int & CDS & & & & \\
\hline Xpm1-06 & $149,432-149,490$ & gi|390577803|gb|AKCZ01000036.1 & $\ldots$ & MBP & 12 & 7 & $8-14$ & 0.758 \\
\hline Xpm1-07 h & $160,439-160,495$ & $\ldots$ & $\ldots$ & $\mathrm{CHP}$ & 12 & 6 & $9-13$ & 0.788 \\
\hline $\mathrm{Xpm} 1-08^{\mathrm{h}}$ & $183,975-184,128$ & $\ldots$ & $\mathrm{X}$ & $\ldots$ & 12 & 7 & $12-22$ & 0.909 \\
\hline $\mathrm{Xpm} 1-15$ & $111,401-111,457$ & gi|390577770|gb|AKCZ01000045.1 & $\ldots$ & $\mathrm{CP}$ & 12 & 7 & $8-18$ & 0.894 \\
\hline $\mathrm{Xpm} 1-18$ & $23,401-23,452$ & gi|390577733|gb|AKCZ01000058.1 & $\ldots$ & PNET & 10 & 7 & $6-13$ & 0.911 \\
\hline Xpm1-19i & $88,411-88,507$ & & $\mathrm{X}$ & $\ldots$ & 12 & 6 & $16-25$ & 0.924 \\
\hline Xpm $1-20^{\mathrm{h}}$ & $42,485-42,521$ & gi|390577711|gb|AKCZ01000065.1 & $\mathrm{X}$ & $\ldots$ & 11 & 6 & $6-9$ & 0.691 \\
\hline $\mathrm{Xpm} 1-21^{\mathrm{h}}$ & $68,745-68,823$ & & $\mathrm{X}$ & $\ldots$ & 10 & 7 & $11-15$ & 0.822 \\
\hline $\mathrm{Xpm} 1-25^{\mathrm{i}}$ & $56,842-56,883$ & gi|390577703|gb|AKCZ01000069.1 & $\ldots$ & HMEP & 12 & 6 & $7-15$ & 0.909 \\
\hline $\mathrm{Xpm} 1-27^{\mathrm{i}}$ & $29,418-29,474$ & gi|390577676|gb|AKCZ01000082.1 & $\mathrm{X}$ & $\ldots$ & 12 & 7 & $8-20$ & 0.864 \\
\hline Xpm1-30i & $44,082-44,143$ & gi|390577664|gb|AKCZ01000088.1 & $\mathrm{X}$ & $\ldots$ & 12 & 7 & $7-14$ & 0.803 \\
\hline $\mathrm{Xpm} 1-31$ & $4,532-4,579$ & gi|390577660|gb|AKCZ01000090.1 & $\ldots$ & PTE & 10 & 7 & $6-11$ & 0.833 \\
\hline $\mathrm{Xpm} 1-35$ & $3,285-3,411$ & gi|390577570|gb|AKCZ01000128.1 & $\ldots$ & $\mathrm{CHP}$ & 9 & 7 & $10-18$ & 0.833 \\
\hline Xpm1-37 & $12,488-12,517$ & gi|390577754|gb|AKCZ01000054.1 & $\ldots$ & $\mathrm{CHP}$ & 12 & 7 & $6-11$ & 0.867 \\
\hline $\mathrm{Xpm} 1-38^{\mathrm{h}}$ & $39,956-40,015$ & gi|390577770|gb|AKCZ01000045.1 & $\ldots$ & PE & 12 & 6 & $11-14$ & 0.654 \\
\hline
\end{tabular}

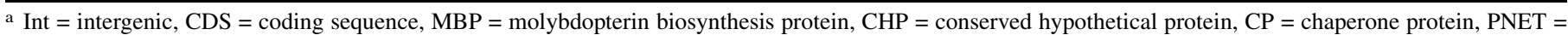
putative $\mathrm{Na}^{+}$extrusion $\mathrm{ABC}$ transporter, HMEP $=$ heavy metal efflux permease, $\mathrm{PTE}=$ putative type III effector, and $\mathrm{PE}=$ putative endoglucanase.

b VNTR locus

c Location of the repeat regions for CIO1 strain.

d Flanking sequences (number of genome sequences out of the 12 genomes for which flanking regions were available).

e Unit length.

f Copy number range.

g Hunter-Gaston discriminatory index using the 12 genomes described in the Methods.

h VNTR locus evaluated by Arrieta-Ortiz et al. (2013).

i VNTR locus evaluated by Trujillo et al. (2014b). 
two loci (Xpm1-37 and Xpm1-08) in strain CIO151 exceeded that for the 99 analyzed Colombian strains and 65 worldwide genomes of $X$. phaseoli pv. manihotis (Table 1). However, the repeat length range for these loci is within the range for strains from Argentina (Table 3).

The HGDI of each of the 15 loci calculated for 12 sequenced strains from Brazil, Colombia, and Uganda was greater than that for the $99 X$. phaseoli pv. manihotis strains from the Colombian Caribbean region. A clear difference was observed for loci Xpm125 and Xpm1-06, in which the variability was strongly reduced in $X$. phaseoli pv. manihotis originating from the Caribbean region.
These loci may be under selection, because they are located within sequences encoding a dihydrodipicolinate synthetase and a molybdopterin biosynthesis protein, respectively.

The MLVA-15 scheme is slightly more discriminatory than AFLP markers. Fifty-five strains previously analyzed with AFLP were also typed using the MLVA-15 scheme. The TRs separated more multilocus genotypes (MLGs) than the AFLP markers, with 52 and 48 MLGs, respectively (Table 4). The HGDI was slightly greater for the MLVA-15 dataset than for the AFLP dataset, with HGDI values of 0.998 and 0.993 , respectively. The numbers of haplotypes for each marker were not entirely consistent

TABLE 3. Specificity of the MLVA-15 scheme: Putative presence of the tandem repeat loci in pathovars of Xanthomonas phaseoli and in other Xanthomonas spp. ${ }^{\mathrm{a}}$

\begin{tabular}{|c|c|c|c|c|c|c|c|c|c|c|c|c|c|c|c|c|}
\hline \multirow[b]{2}{*}{ Xanthomonas pathovars and species ${ }^{c}$} & \multirow[b]{2}{*}{$n$} & \multicolumn{15}{|c|}{ VNTRs (Xpm-) ${ }^{\mathrm{b}}$} \\
\hline & & 06 & 07 & 08 & 15 & 18 & 19 & 20 & 21 & 25 & 27 & 30 & 31 & 35 & 37 & 38 \\
\hline \multicolumn{17}{|l|}{$X$. phaseoli pvs. } \\
\hline manihotis ARG & 8 & $10-11$ & $6-10$ & $11-37$ & $9-16$ & $8-12$ & $13-22$ & $6-10$ & $14-23$ & $3-16$ & $9-12$ & $14-27$ & $5-11$ & $13-23$ & $6-21$ & $7-11$ \\
\hline phaseoli & 1 & 6 & 9 & 5 & 23 & ND & 11 & 5 & 13 & 7 & 13 & 15 & 3 & 25 & 16 & 2 \\
\hline \multicolumn{17}{|l|}{$X$. citri pvs. } \\
\hline malvacearum & 2 & ND & ND & ND & ND & ND & 2 & ND & ND & $10-16$ & 20 & 9 & $5-6$ & ND & 32 & 5 \\
\hline X. axonopodis pv. dieffenbachiae & 1 & ND & ND & 7 & 13 & ND & 8 & 8 & ND & 8 & ND & ND & 4 & ND & 8 & 13 \\
\hline X. euvesicatoria & 2 & ND & ND & ND & ND & 6 & 2 & ND & ND & ND & ND & ND & $3-4$ & ND & ND & 5 \\
\hline X. alfafae pv. alfafae & 1 & ND & ND & ND & ND & 4 & 2 & ND & 4 & ND & ND & 9 & ND & ND & ND & 7 \\
\hline$X$. cassavae & 1 & 6 & ND & ND & ND & ND & ND & ND & ND & 8 & ND & ND & ND & ND & $\mathrm{D}$ & ND \\
\hline X. translucens pv. translucens & 2 & ND & ND & ND & ND & ND & 13 & ND & ND & ND & ND & 8 & ND & ND & ND & 2 \\
\hline \multicolumn{17}{|l|}{ X. oryzae } \\
\hline oryzae (Asia) & 1 & ND & ND & 4 & ND & ND & ND & ND & ND & ND & ND & ND & ND & ND & ND & ND \\
\hline
\end{tabular}

a The multiple loci variable number of tandem repeat analysis (MLVA)-15 scheme comprises 15 variable number of tandem repeat (VNTR) loci.

${ }^{\mathrm{b}} \mathrm{ND}=$ not detected (i.e., no amplicon observed) and $\mathrm{D}=$ detected (an amplicon was observed but TR was not deduced due to the size of the array).

c X. phaseoli pv. manihotis from the Caribbean region of Colombia (COL) and from Argentina (ARG), X. phaseoli pv. phaseoli (= X. campestris pv. phaseoli 85-6), $X$. citri pv. glycines (CIX235, CIX2426), X. citri pv. malvacearum (=X. axonopodis pv. malvacearum; CFBP2036 and CIX737), X. axonopodis pv. dieffenbachiae (CIX227), X. citri pv. vignicola (= X. campestris pv. vignicola; CIX234), X. euvesicatoria (CIX 270 and CIX1931), X. alfafae pv. alfafae (CIX203), X. cassavae CFBP2642 = LMG673, X. translucens pv. translucens (CFBP2054 and CFBP2544), and X. oryzae pv. oryzae from Asia (PXO86) and from Africa (BAI3). CFBP = Collection Française des Bactéries Phytopathogènes, Angers, France; and CIX = collection from UMR IPME, Montpellier, France.

TABLE 4. Tandem repeat sequence and MLVA-15 microsatellite scheme description ${ }^{\mathrm{a}}$

\begin{tabular}{|c|c|c|c|c|c|c|c|}
\hline \multirow[b]{2}{*}{ Pool } & \multirow[b]{2}{*}{ VNTR locus } & \multicolumn{2}{|c|}{$\begin{array}{l}\text { Amplicon length for } \\
\text { strains }\end{array}$} & \multirow[b]{2}{*}{ Alleles ${ }^{\mathrm{b}}$} & \multirow[b]{2}{*}{ VNTR sequence of the reference strain } & \multirow[b]{2}{*}{$\mathrm{HGDI}^{\mathrm{c}}$} & \multirow{2}{*}{$\begin{array}{l}\text { VNTR locus } \\
\text { nomenclature }\end{array}$} \\
\hline & & Tested & Reference & & & & \\
\hline \multirow{2}{*}{1} & Xpm1-08d & $191-246$ & 349 & $14-22$ & GGATTTG(2) GGGATTT(18) GGGGATT(15) GGGGAAT(1) CGGGAAT(1) & 0.74 & $\mathrm{XaG} 2 \_106^{\mathrm{e}}$ \\
\hline & Xpm1-15 & 288-387 & 346 & $8-22$ & ACTCCCC(1) ATTCCCC(7) ATTCCCG(5) AATCCCG(3) & 0.85 & $\ldots$ \\
\hline \multirow[t]{2}{*}{2} & Xpm1-18 & $182-230$ & 189 & $7-14$ & TTCGGGA(4) ATCGGGA(3) ATCGTCA(1) & 0.69 & \\
\hline & $\mathrm{Xpm} 1-21^{\mathrm{d}}$ & $188-260$ & 189 & $14-24$ & AATCCGC(6) AGTCCGC(1) AATCCGC(1) AATCCCC(4) GCTTCAC(2) & 0.52 & XaG1_70 e \\
\hline \multirow[t]{4}{*}{3} & Xpm1-06 & $185-221$ & 192 & $9-14$ & $\begin{array}{l}\text { AATCGGG(1) AATGGGG(2) AATCGGG(1) AATCGAG(1) ATTCGAG(1) } \\
\text { ATTTGGG(1) AGTCGGG(2) AGTCGTT(1) }\end{array}$ & 0.08 & $\ldots$ \\
\hline & Xpm1-07d & $82-118$ & 83 & $6-12$ & GGTGTG(2) GGTGTC(4) & 0.69 & XaG1_65e \\
\hline & Xpm1-20d & $278-326$ & 296 & $4-12$ & $\operatorname{GCACCG}(7)$ & 0.34 & XaG1_71e \\
\hline & Xpm1-38d & 179-203 & 197 & $7-11$ & CCCACT(6) CCCACA(1) CCAACG(1) CCGACG(2) & 0.57 & XaG1_58 \\
\hline 4 & Xpm1-19f & $211-252$ & 234 & $15-22$ & TCGGTA(5) TCGGTG(3) TCGGCG(2) TCGGTG(8) TCGGCG(1) & 0.76 & XaG1_67g \\
\hline
\end{tabular}

\footnotetext{
a The multiple loci variable number of tandem repeat analysis (MLVA)-15 scheme comprises 15 variable number of tandem repeat (VNTR) loci. Application on 99 $X$. phaseoli pv. manihotis strains from the Caribbean region of Colombia and the MLVA haplotype of the reference strain (CIO151).

b Allelic range observed from analysis of $99 X$. phaseoli pv. manihotis strains.

c Hunter-Gaston discriminatory index using the 12 genomes described in the Methods.

d Names starting with Xam were changed for Xpm (Arrieta-Ortiz et al. 2013).

e VNTR locus nomenclature from Arrieta-Ortiz et al. (2013).

f Trujillo et al. (2014a).

$\mathrm{g}$ VNTR locus nomenclature from Trujillo et al. (2014a).
} 
(i.e., several AFLP haplotypes corresponded to a unique MLVA haplotype and vice versa). However, the Mantel test results suggested that the data obtained from the two genotyping techniques were congruent. The value of correlations between genetic distances of individual pairs observed for the AFLP and MLVA data were highly significant $(r=0.503 ; P<0.001)$.

The genotype accumulation curve showed that a plateau was reached with 15 loci (Fig. 2). Eleven loci were almost sufficient to discriminate $90 \%$ of the genotypes. The genotypic resolution analysis of our MLVA scheme showed that the 15 VNTR loci allowed accurate determination of the number of genotypes in the sample.

Analysis of the TR number variation producing each SLV of the different clonal complexes concerned eight loci involved in singlelocus variation. In all, 14 of the 16 SLVs $(87.5 \%)$ were singlerepeats variants (SRVs). A notable exception was locus 15, at which one SRV and one 10-repeats variant (RV) were observed. This tendency for a predominant stepwise mutation model for most loci needs to be confirmed using a larger sample of SLVs.

The MLVA-15 scheme revealed large $X$. phaseoli pv. manihotis haplotypic diversity in the Colombian Caribbean region. Our MLVA-15 scheme distinguished 88 haplotypes $(88.9 \%)$ from the collection of $X$. phaseoli pv. manihotis strains $(n=$ 99) isolated from 2008 to 2015 in four localities of the Colombian Caribbean region. No haplotype was shared by strains from different localities or by strains isolated in different years (Fig. $3 \mathrm{~A}$ and $\mathrm{B}$ ). Most of the strains originating from the same locality at the same time could be discriminated. In some cases, strains collected in the same year and from the same field and locality were classified into different haplotypes. For example, two fields were sampled in Chinú during 2013, including one strain isolated from one field and four strains isolated from another field. Every strain belonged to a different haplotype. In other cases, strains collected in the same year from the same field could belong to the same or to different haplotypes. For example, two fields were sampled in Chinú during 2014, yielding one strain from one field and four strains from another field. Two of the four strains from the same field belonged to the same haplotype, whereas the other two strains from the same field and the strain from a different field were classified into different haplotypes. Eleven small clonal complexes (CCs) grouping two to five SLVs were defined (Fig. 3A). Ten CCs originated from the same locality, among which five $\mathrm{CCs}$ grouped strains isolated in different years and five contained only strains isolated in the same year. Strains from the localities of San Jacinto, Palmitos, and Ciénaga de Oro isolated in different years were grouped in CC3. Four of the six multiyear CCs were maintained for at least four years (CCs 2, 3, 6, and 10) (Fig. 3B). Strains originating from Chinú were less genetically related ( $\geq 4$ locus variants) to strains from other localities.

Pairwise comparisons of the four localities for the two collection periods showed significant differentiation between the strains from Chinú isolated from 2008 to 2010 and the other collections (Supplementary Table S3). Populations from Chinú or San Jacinto isolated from 2013 to 2015 were significantly differentiated in some cases. The populations from Ciénaga de Oro or San Jacinto isolated from 2008 to 2010 were not significantly differentiated from those collected from 2013 to 2015.

The MLVA-15 scheme is highly specific to $X$. phaseoli. All analyzed strains from Colombia and $X$. phaseoli pv. manihotis strains from Argentina produced amplicons for all 15 TR loci (Table 3). We evaluated a single strain of X. phaseoli pv. phaseoli, which produced amplicons for 14 of 15 TR loci. Four loci were amplified for all strains of different pathovars of $X$. citri, with up to eight TR loci for one strain of $X$. axonopodis pv. dieffenbachiae. Strains from other species produced very few amplicons when tested with the 15 TR loci, including the strain of $X$. cassavae which is a foliar pathogen of cassava. Therefore, this scheme is useful for population studies in $X$. phaseoli pv. manihotis and in other members of this species. However, the scheme cannot be used for other species in the same genus.

\section{DISCUSSION}

The ability to discriminate between closely related strains is important in epidemiology for distinguishing subspecific strains, determining successive changes in pathogen populations, and identifying inoculum sources or transmission pathways. The MLVA scheme reported here has a potential to be used in other countries of the world for these strategies. This scheme can contribute to control of CBB due to its simplicity in implementation, safety, high discriminatory power, reproducibility, and portability between laboratories. Additionally, the developed scheme is composed of 15 VNTR loci, with which we expect to reduce the effect of homoplasy events and avoid biases due to genetic inferences (Estoup et al. 2002). The 15 VNTR loci reported in this study allowed analysis of the genetic diversity of $X$. phaseoli $\mathrm{pv}$. manihotis with slightly better discrimination than previous AFLP schemes. Although the AFLP technique is also a multilocus approach, it is more time consuming and technically demanding. However, the biggest disadvantage of the use of AFLP and similar fingerprinting techniques as typing methods for epidemiological purposes is their lack of reproducibility at the intra- and interlaboratory levels (Bui Thi Ngoc et al. 2009a; Kremer et al. 2005; Sunnucks 2000). In addition, the MLVA approach targets single-locus markers that can be analyzed as gene genealogies and allele frequencies, which makes the results more informative for population structure and molecular epidemiology analyses.

The discriminatory power of a typing scheme is an important characteristic for typing method development (Bricker and Ewalt 2005; Kremer et al. 2005; van Belkum et al. 2001). Recently, two major typing methods were used for bacterial diversity analyses. For example, when Xanthomonas strains isolated from rice or citrus were typed using AFLP and MLVA targeting TRs with similar sizes, such as in our MLVA-15 scheme, MLVA had a similar discriminatory power (Zhao et al. 2012) or even a higher discriminatory power (Bui Thi Ngoc et al. 2009a). Comparisons of AFLP and MLVA schemes for $X$. citri pv. citri strains demonstrated a greater discriminatory power for the scheme formed by 14 loci (Pruvost et al. 2014). Our results for $X$. phaseoli pv. manihotis are in agreement with these observations and are also consistent with a previous report for $X$. phaseoli pv. manihotis (Trujillo et al. 2014a). In addition, AFLP analyses are at risk for underestimating clonal diversity due to lower resolution, whereas microsatellites are more efficient at differentiating among clones due to a greater mutation rate (Arnaud-Haond et al. 2005, 2007). The genetic variation patterns revealed by the codominant VNTRs were correlated with those from the binary AFLP markers, indicating that both markers

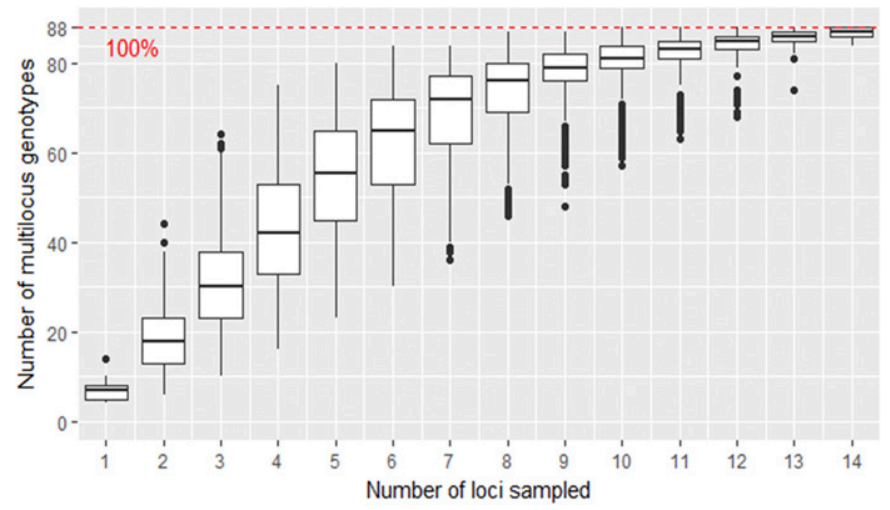

Fig. 2. Genotype accumulation curve for Xanthomonas phaseoli pv. manihotis populations collected in the Colombian Caribbean region. 
were suitable for analysis of $X$. phaseoli pv. manihotis diversity. However, depending on the research questions, the advantages and disadvantages of each marker should be determined to choose the most appropriate method (Maguire et al. 2002). The genotypic resolution analysis of our MLVA scheme, which includes 10 more loci than the scheme used by Trujillo et al. (2014a), allowed accurate determination of the number of genotypes in the $X$. phaseoli pv. manihotis strains of the Colombian Caribbean region. The genetic diversity could be completely estimated for strains collected in a very localized region of Colombia using 11 VNTR loci. The scheme is efficient in discriminating strains not only from this specific collection from the northern coast of

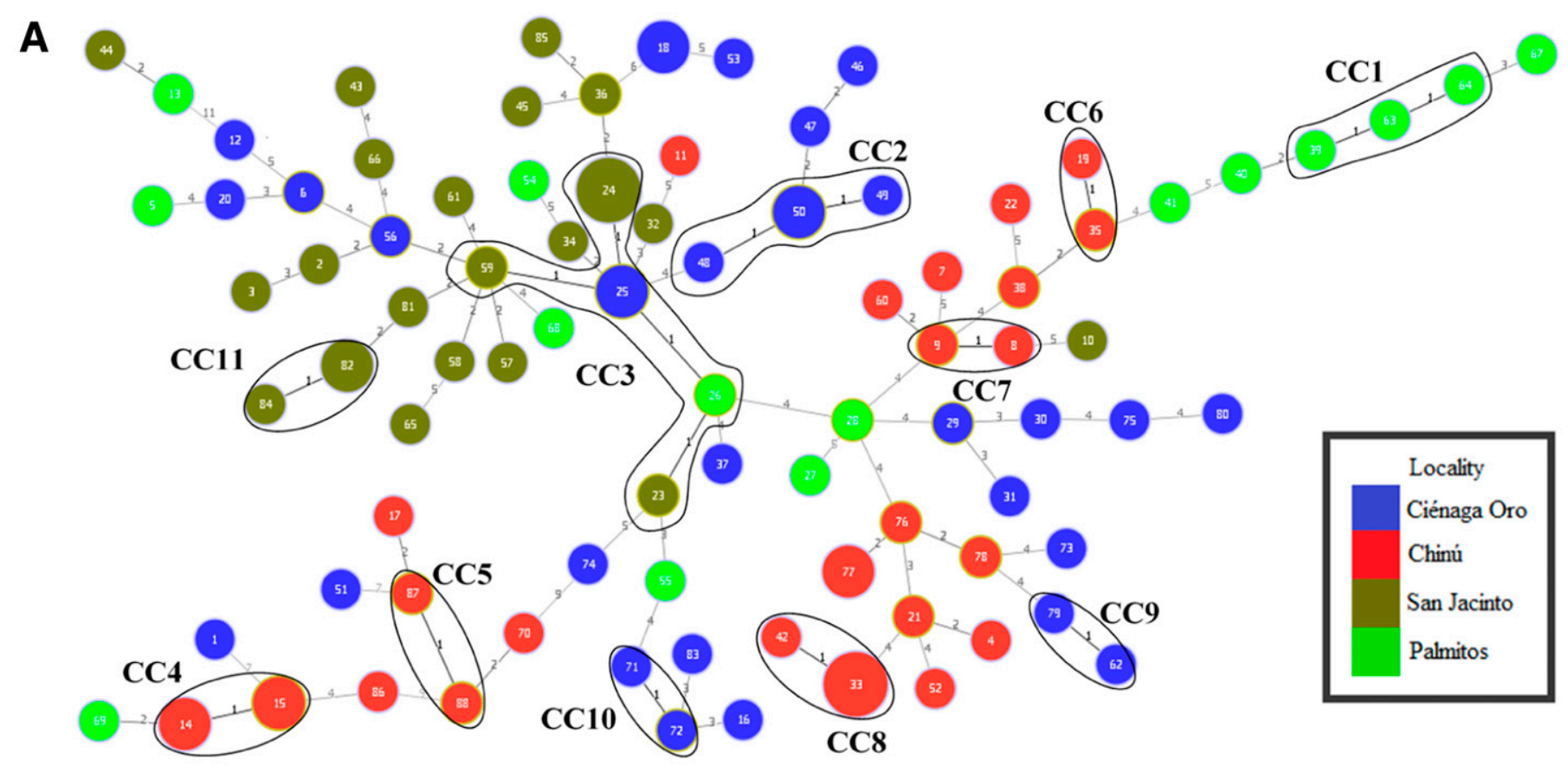

B

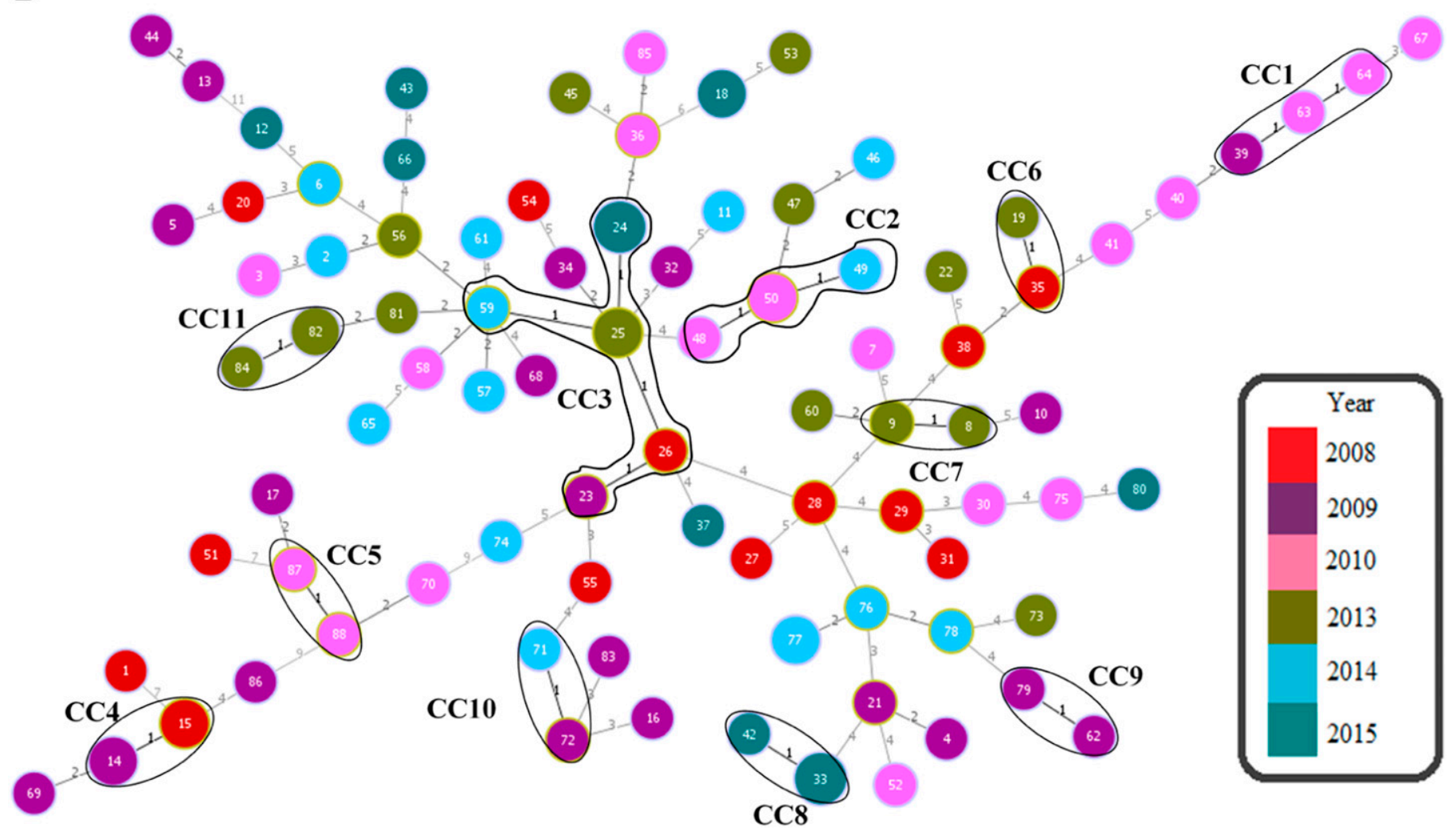

Fig. 3. Minimum spanning tree of Xanthomonas phaseoli pv. manihotis populations by A, locality and B, year. Using the global optimal eBURST algorithm, 11 clonal complexes are visualized at a level of one single-locus variance. 
Colombia but also those from Argentina, therefore demonstrating its potential use for other countries in the world.

Other important aspects for routine analysis are the cost and the rapidity with which results can be obtained. The highlight of this MLVA approach is the standardized multiplex PCR, because three or four loci can be analyzed per strain at the same time in a single reaction, resulting in reduced costs. In addition, the costs can be further decreased using the boiling procedure to obtain template DNA of sufficient quality for PCR amplification rather than using a DNA extraction kit, because the technique does not require highly purified DNA. In terms of time, this scheme allows faster analysis of genetic diversity than other common techniques, because several strains can be analyzed in a short period of time (Trujillo et al. 2014a). Typing of 96 strains in a microplate with the MLVA-15 scheme is obtained in approximately 3 days. Other important criteria for typing schemes are reproducibility and portability, which highlight clear advantages for MLVA in the epidemiological monitoring of different pathogen populations such as Streptococcus pneumoniae (Elberse et al. 2011), X. citri pv. citri (Pruvost et al. 2014), and Ralstonia pseudosolanacearum (Guinard et al. 2017). Although, unfortunately, we did not have access to the 65 strains corresponding to the published genomes to verify the portability, this characteristic was demonstrated with a few $X$. phaseoli pv. manihotis strains analyzed in two different laboratories. As a result, identical genetic patterns were produced, showing the portability of our MLVA-15 scheme.

Markers with high mutation rates provide greater discriminatory power at small spatio-temporal scales, as is the case for closely related strains during outbreaks. Our MLVA-15 scheme distinguished $88.9 \%$ of haplotypes within the X. phaseoli pv. manihotis strain collection originating from the Colombian Caribbean region, which was isolated over a 7-year period. Most strains isolated from the same locality in the same year were discriminated into different haplotypes by the MLVA-15 scheme. Closely related strains (i.e., SLVs within a clonal complex from the same field and double-locus variants within a clonal complex from different fields) occurred as expected based on the diversification process; however, more genetically distant strains were also observed. This observation suggests that different populations may coexist in the same locality. No haplotype grouped strains from different localities or isolated in different years, probably due to sampling biases. This MLVA scheme appears to be well adapted for describing genetic diversity at the locality level. Sampling at the field level or the plant level will allow evaluation of the discriminatory power of the MLVA-15 scheme at lower levels. The SLVs of three CCs with unique geographical strain origins were isolated over a period of 4 or 5 years. Some haplotypes or closely related haplotypes can be maintained for several years, and this phylogenetic signature can persist and be detected by the MLVA-15 scheme. DNA sequencing of some of these alleles can confirm that this effect is not the result of size homoplasy.

Strains from different localities were found to be epidemiologically related (e.g., belonging to the same clonal complex); because these locations are at geographical distances ranging between 46 and $163 \mathrm{~km}$, we consider that this common genealogy could be the result of transportation of infected plant material through cuttings. This conclusion is supported by the lack of genetic differentiation between strains from these two localities. Exchange of plant material within ecozones and fields and between ecozones in Colombia was also reported by Restrepo and Verdier (1997) and Trujillo et al. (2014b) in the Caribbean locations. The observed changes in allelic diversity highlight the importance of continuously monitoring the diversity of $X$. phaseoli pv. manihotis populations in the Colombian Caribbean region and the need for an adapted typing system to provide suitable epidemiological data and diversity estimates to improve CBB control measures (López et al. 2007; Vera Cruz et al. 2000).
The MLVA-15 scheme showed a great specificity to the different pathovars of $X$. phaseoli tested. This could support some transferability of this genotyping tool within this species. Such intraspecies transferability of VNTR loci has already been successful within X. citri (Bui Thi Ngoc et al. 2009b; Pruvost et al. 2011). PCR amplifications of the TR loci were poorly successful except for some TR markers on pathovars of $X$. citri. Only two TRs targeted by the MLVA-15 scheme were amplified in $X$. cassavae causing cassava bacterial leaf spot, which has a minor impact on cassava production compared with CBB. Cassava leaf spot disease is mostly distributed in Africa and colonies of the bacterial pathogen are yellow but the foliar symptoms can be confusing. A direct genotyping procedure from leaf-tissue using our MLVA-15 scheme will discriminate the two cassava pathogens.

In conclusion, the MLVA-15 scheme describes effective molecular markers for molecular typing of $X$. phaseoli $\mathrm{pv}$. manihotis strains and genetic diversity studies. This new scheme comprises several advantages, including its discriminatory power, low cost, ease of performance, and superior reproducibility.

\section{LITERATURE CITED}

Abaca, A., Kiryowa, M., Awori, E., Andema, A., Dradiku, F., Moja, A., and Mukalazi, J. 2014. Cassava pests and diseases' prevalence and performance as revealed by adaptive trial sites in north western agro-ecological zone of Uganda. J. Agric. Sci. 6:116-122.

Achtman, M. 2008. Evolution, population structure, and phylogeography of genetically monomorphic bacterial pathogens. Annu. Rev. Microbiol. 62: 53-70.

Arnaud-Haond, S., Alberto, F., Teixeira, S., Procaccini, G., Serrão, E., and Duarte, C. 2005. Assessing genetic diversity in clonal organisms: Low diversity or low resolution? Combining power and cost efficiency in selecting markers. J. Hered. 96:434-440.

Arnaud-Haond, S., Duarte, C. M., Alberto, F., and Serrão, E. A. 2007. Standardizing methods to address clonality in population studies. Mol. Ecol. 16: 5115-5139.

Arrieta-Ortiz, M., Rodríguez-R, L. M., Pérez-Quintero, A. L., Poulin, L., Díaz, A. C., and Arias Rojas, N. 2013. Genomic survey of pathogenicity determinants and VNTR markers in the cassava bacterial pathogen Xanthomonas axonopodis pv. manihotis strain CIO151. PLoS One 8:e79704.

Bart, R., Cohn, M., McCallum, E. J., Shybut, M., Petriello, A., and Krasileva, K. 2012. High-throughput genomic sequencing of cassava bacterial blight strains identifies conserved effectors to target for durable resistance. Proc. Natl. Acad. Sci. U.S.A. 109:E1972-E1979.

Bergsma-Vlami, M., Martin, W., Koenraadt, H., Teunissen, H., Pothier, J. F., Duffy, B. 2012. Molecular typing of Dutch isolates of Xanthomonas arboricola pv. pruni isolated from ornamental cherry laurel. J. Plant Pathol. 94:29-35.

Bernal, A., López, C., Trujillo, C., Medina, C., García, S., Restrepo, M. 2011. El cultivo de la yuca. Enfermedades, Bogotá, Colombia.

Bernal-Galeano, V., Ochoa, J. C., Trujillo, C., Rache, L., Bernal, A., and López, C. 2018. Development of a multiplex nested PCR method for detection of Xanthomonas axonopodis pv. manihotis in cassava. Trop. Plant Pathol. 43:341-350.

Boher, B., and Verdier, V. 1994. Cassava bacterial blight in Africa: The state of knowledge and implications for designing control strategies. Afr. Crop Sci. J. 2:505-509.

Boudon, S., Manceau, C., and Nottéghem, J.-L. 2005. Structure and origin of Xanthomonas arboricola pv. pruni populations causing bacterial spot of stone fruit trees in western Europe. Phytopathology 95:1081-1088.

Bricker, B. J., and Ewalt, D. R. 2005. Evaluation of the HOOF-Print assay for typing Brucella abortus strains isolated from cattle in the United States: Results with four performance criteria. BMC Microbiol. 5:37.

Bühlmann, A., Dreo, T., Rezzonico, F., Pothier, J. F., Smits, T. H. M., and Ravnikar, M. 2014. Phylogeography and population structure of the biologically invasive phytopathogen Erwinia amylovora inferred using minisatellites. Environ. Microbiol. 16:2112-2125.

Bui Thi Ngoc, L., Vernière, C., Jarne, P., Brisse, S., Guérin, F., Boutry, S., Gagnevin, L., and Pruvost, O. 2009a. From local surveys to global surveillance: Three high-throughput genotyping methods for epidemiological monitoring of Xanthomonas citri pv. citri pathotypes. Appl. Environ. Microbiol. 75:1173-1184.

Bui Thi Ngoc, L., Vernière, C., Vital, K., Guerin, F., Gagnevin, L., and Brisse, S. 2009b. Development of 14 minisatellite markers for the citrus canker bacterium, Xanthomonas citri pv. citri. Mol. Ecol. Resour. 9:125-127. 
Castiblanco, L., Gil, J., Rojas, A., Osorio, D., Gutiérrez, S., and Muñoz-Bodnar, A. 2013. TALE1 from Xanthomonas axonopodis pv. manihotis acts as a transcriptional activator in plant cells and is important for pathogenicity in cassava plants. Mol. Plant Pathol. 14:84-95.

Cesbron, S., Pothier, J., Gironde, S., Jacques, M.-A., and Manceau, C. 2014. Development of multilocus variable-number tandem repeat analysis (MLVA) for Xanthomonas arboricola pathovars. J. Microbiol. Methods 100:84-90.

Chenal-Francisque, V., Diancourt, L., Cantinelli, T., Passet, V., Tran-Hykes, C., and Bracq-Dieye, H. 2013. Optimized multilocus variable-number tandem-repeat analysis assay and its complementarity with pulsed-field gel electrophoresis and multilocus sequence typing for Listeria monocytogenes clone identification and surveillance. J. Clin. Microbiol. 51:1868-1880.

Coletta-Filho, H. D., Takita, M. A., de Souza, A. A., Aguilar-Vildoso, C. I., and Machado, M. A. 2001. Differentiation of strains of Xylella fastidiosa by a variable number of tandem repeat analysis. Appl. Environ. Microbiol. 67: 4091-4095.

Constantin, E. C., Cleenwerck, I., Maes, M., Baeyen, S., Van Malderghem, C., and De Vos, P. 2016. Genetic characterization of strains named as Xanthomonas axonopodis pv. dieffenbachiae leads to a taxonomic revision of the $X$. axonopodis species complex. Plant Pathol. 65:792-806.

Elberse, K. E. M., Nunes, S., Sá-Leão, R., van der Heide, H. G. J., and Schouls, L. M. 2011. Multiple-locus variable number tandem repeat analysis for Streptococcus pneumoniae: Comparison with PFGE and MLST. PLoS One 6:e19668.

Estoup, A., Jarne, P., and Cornuet, J.-M. 2002. Homoplasy and mutation model at microsatellite loci and their consequences for population genetics analysis. Mol. Ecol. 11:1591-1604.

Excoffier, L., Laval, G., and Schneider, S. 2005. Arlequin (version 3.0): An integrated software package for population genetics data analysis. Evol. Bioinf. Online 1:47-50.

Fanou, A. A., Amégnikin Zinsou, V., and Wydra, K. 2018. Cassava bacterial blight: A devastating disease of cassava. Pages 13-36 in: Cassava. V. Waisundara, ed. IntechOpen, Erfurt, Germany.

Francisco, A. P., Vaz, C., Monteiro, P., Melo-Cristino, J., Ramirez, M., and Carriço, J. A. 2012. PHYLOViZ: Phylogenetic inference and data visualization for sequence based typing methods. BMC Bioinf. 13:87.

Grünwald, N. J., Kamvar, Z. N., and Everhart, S. E. 2015. Population Genetics in $\mathrm{R}$.

Guinard, J., Latreille, A., Guérin, F., Poussier, S., and Wicker, E. 2017. New multilocus variable-number tandem repeat analysis (MLVA) scheme for fine-scale monitoring and microevolution-related study of Ralstonia pseudosolanacearum phylotype I populations. Appl. Environ. Microbiol. 83: e03095-16.

Hunter, P. R., and Gaston, M. A. 1988. Numerical index of the discriminatory ability of typing systems: An application of Simpson's index of diversity. J. Clin. Microbiol. 26:2465-2466.

Kremer, K., Arnold, C., Cataldi, A., Gutiérrez, M., Haas, W. H., and Panaiotov, S. 2005. Discriminatory power and reproducibility of novel DNA typing methods for Mycobacterium tuberculosis complex strains. J. Clin. Microbiol. 43:5628-5638.

Leduc, A., Traoré, Y. N., Boyer, K., Magne, M., Grygiel, P., and Juhasz, C. C. 2015. Bridgehead invasion of a monomorphic plant pathogenic bacterium: Xanthomonas citri pv. citri, an emerging citrus pathogen in Mali and Burkina Faso. Environ. Microbiol. 17:4429-4442.

Li, W., Raoult, D., and Fournier, P. E. 2009. Bacterial strain typing in the genomic era. FEMS Microbiol. Rev. 33:892-916

Lindstedt, B. A. 2005. Multiple-locus variable number tandem repeats analysis for genetic fingerprinting of pathogenic bacteria. Electrophoresis 26: 2567-2582.

López, C., Restrepo, S., and Verdier, V. 2007. Limitations of cassava bacterial blight: New advances. Acta Biol. Colomb. 11:21-45.

Lozano, J. 1986. Cassava bacterial blight: A manageable disease. Plant Dis. 70:1089-1093

Lozano, J., and Sequeira, L. 1974. Bacterial blight of cassava in Colombia: Epidemiology and control. Phytopathology 64:83-88.

Maguire, T. L., Peakall, R., and Saenger, P. 2002. Comparative analysis of genetic diversity in the mangrove species Avicennia marina (Forsk.) Vierh. (Avicenniaceae) detected by AFLPs and SSRs. Theor. Appl. Genet. 104: 388-398.

Mansfield, J., Genin, S., Magori, S., Citovsky, V., Sriariyanum, M., and Ronald, P. 2012. Top 10 plant pathogenic bacteria in molecular plant pathology. Mol. Plant Pathol. 13:614-629.

Mantel, N. 1967. The detection of disease clustering and a generalized regression approach. Cancer Res. 27:209-220.

Ogunjobi, A. A., Fagade, O. E., and Dixon, A. G. O. 2006. Molecular variation in population structure of Xanthomonas axonopodis pv. manihotis in the south eastern Nigeria. Afr. J. Biotechnol. 5:1868-1872.
Ogunjobi, A. A., Fagade, O. E., and Dixon, A. G. O. 2008. Physiological studies on Xanthomonas axonopodis pv. manihotis (Xam) strains isolated in Nigeria. Adv. Biol. Res. 2:90-96.

Ogunjobi, A. A., Fagade, O. E., and Dixon, A. G. O. 2010. Comparative analysis of genetic variation among Xanthomonas axonopodis pv. manihotis isolated from the western states of Nigeria using RAPD and AFLP. Indian J. Microbiol. 50:132-138.

Oren, A., and Garrity, G. M. 2016. Notification of changes in taxonomic opinion previously published outside the IJSEM. Int. J. Syst. Evol. Microbiol. 66:2469-2470.

Peakall, R., and Smouse, P. 2012. GenAlEx 6.5: Genetic analysis in Excel. Population genetic software for teaching and research-an update. Bioinformatics 28:2537-2539.

Poulin, L., Grygiel, P., Magne, M., Gagnevin, L., Rodriguez-R, L. M., Forero Serna, N., Zhao, S., El Rafii, M., and Dao, S. 2015. New multilocus variable-number tandem-repeat analysis tool for surveillance and local epidemiology of bacterial leaf blight and bacterial leaf streak of rice caused by Xanthomonas oryzae. Appl. Environ. Microbiol. 81:688-698.

Pruvost, O., Magne, M., Boyer, K., Leduc, A., Tourterel, C., and Drevet, C. 2014. A MLVA genotyping scheme for global surveillance of the citrus pathogen Xanthomonas citri pv. citri suggests a worldwide geographical expansion of a single genetic lineage. PLoS One 9:e98129.

Pruvost, O., Vernière, C., Vital, K., Guérin, F., Jouen, E., and Chiroleu, F. 2011. Insertion sequence- and tandem repeat-based genotyping techniques for Xanthomonas citri pv. mangiferaeindicae. Phytopathology 101:887-893.

Restrepo, S., Duque, M., Tohme, J., and Verdier, V. 1999a. AFLP fingerprinting: An efficient technique for detecting genetic variation of Xanthomonas axonopodis pv. manihotis. Microbiology 145:107-114.

Restrepo, S., Valle, T. L., Duque, M. C., and Verdier, V. 1999b. Assessing genetic variability among Brazilian strains of Xanthomonas axonopodis pv. manihotis through restriction fragment length polymorphism and amplified fragment length polymorphism analyses. Can. J. Microbiol. 45:754-763.

Restrepo, S., Velez, C. M., Duque, M. C., and Verdier, V. 2004. Genetic structure and population dynamics of Xanthomonas axonopodis pv. manihotis in Colombia from 1995 to 1999. Appl. Environ. Microbiol. 70: 255-261

Restrepo, S., Vélez, C. M., and Verdier, V. 2000. Measuring the genetic diversity of Xanthomonas axonopodis pv. manihotis within different fields in Colombia. Phytopathology 90:683-690.

Restrepo, S., and Verdier, V. 1997. Geographical differentiation of the population of Xanthomonas axonopodis pv. manihotis in Colombia. Appl. Environ. Microbiol. 63:4427-4434.

Sunnucks, P. 2000. Efficient genetic markers for population biology. Trends Ecol. Evol. 15:199-203.

Trujillo, C. A., Arias-Rojas, N., Poulin, L., Medina, C. A., Tapiero, A., and Restrepo, S. 2014a. Population typing of the causal agent of cassava bacterial blight in the Eastern Plains of Colombia using two types of molecular markers. BMC Microbiol. 14:161.

Trujillo, C. A., Ochoa, J. C., Mideros, M. F., Restrepo, S., López, C., and Bernal, A. 2014b. A complex population structure of the cassava pathogen Xanthomonas axonopodis pv. manihotis in recent years in the Caribbean Region of Colombia. Microb. Ecol. 68:155-167.

U'Ren, J. M., Schupp, J. M., Pearson, T., Hornstra, H., Clark Friedman, C. L., Smith, K. L., Leadem Daugherty, R. R., Rhoton, S. D., Leadem, B., Georgia, S., Cardon, M., Huynh, L. Y., DeShazer, D., Harvey, S. P., Robinson, R., Gal, D., Mayo, M. J., Wagner, D., Currie, B. J., and Keim, P. 2007. Tandem repeat regions within the Burkholderia pseudomallei genome and their application for high resolution genotyping. BMC Microbiol. 7:23.

Van Belkum, A. 2007. Tracing isolates of bacterial species by multilocus variable number of tandem repeat analysis (MLVA). FEMS Immunol. Med. Microbiol. 49:22-27.

Van Belkum, A., Struelens, M., de Visser, A., Verbrugh, H., and Tibayrenc, M. 2001. Role of genomic typing in taxonomy, evolutionary genetics, and microbial epidemiology. Clin. Microbiol. Rev. 14:547-560.

Vera Cruz, C. M., Bai, J., Oña, I., Leung, H., Nelson, R. J., Mew, T.-W., and Leach, J. E. 2000. Predicting durability of a disease resistance gene based on an assessment of the fitness loss and epidemiological consequences of avirulence gene mutation. Proc. Natl. Acad. Sci. U.S.A. 97:13500-13505.

Verdier, V., Dongo, P., and Boher, B. 1993. Assessment of genetic diversity among strains of Xanthomonas campestris pv. manihotis. J. Gen. Microbiol. 139:2591-2601

Verdier, V., Restrepo, S., Mosquera, G., Duque, M., Gerstl, A., and Laberry, R. 1998. Genetic and pathogenic variation of Xanthomonas axonopodis pv. manihotis in Venezuela. Plant Pathol. 47:601-608.

Vernière, C., Bui Thi Ngoc, L., Jarne, P., Ravigné, V., Guérin, F., and Gagnevin, L. 2014. Highly polymorphic markers reveal the establishment of an invasive lineage of the citrus bacterial pathogen Xanthomonas citri pv. citri in its area of origin. Environ. Microbiol. 16:2226-2237. 
Wydra, K., and Verdier, V. 2002. Occurrence of cassava diseases in relation to environmental, agronomic and plant characteristics. Agric. Ecosyst. Environ. 93:211-226.

Yan, S., Yang, Y., Wang, T., Zhao, T., and Schaad, N. W. 2013. Genetic diversity analysis of Acidovorax citrulli in China. Eur. J. Plant Pathol. 136: 171-181.

Young, J. M., Park, D. C., Shearman, H. M., and Fargier, E. 2008. A multilocus sequence analysis of the genus Xanthomonas. Syst. Appl. Microbiol. 31:366-377.
Zaluga, J., Stragier, P., Van Vaerenbergh, J., Maes, M., and De Vos, P. 2013. Multilocus variable-number-tandem-repeats analysis (MLVA) distinguishes a clonal complex of Clavibacter michiganensis subsp. michiganensis strains isolated from recent outbreaks of bacterial wilt and canker in Belgium. BMC Microbiol. 13:126.

Zhao, S., Poulin, L., Rodriguez-R, L., Forero, N., Liu, S.-Y., and Wonni, I. 2012. Development of a variable number of tandem repeats typing scheme for the bacterial rice pathogen Xanthomonas oryzae pv. oryzicola. Phytopathology 102:948-956. 